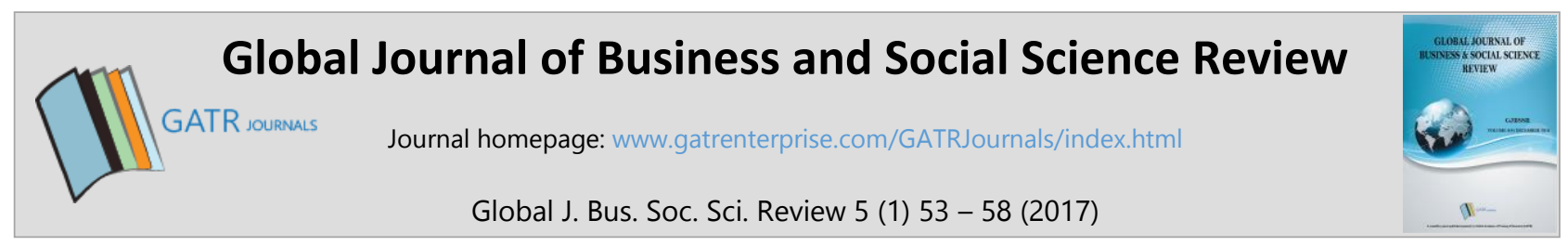

\title{
Does Government Quality Spending can reduce Poverty? A Case in East Java Province
}

\author{
Candra Fajri Ananda ${ }^{1 *}$, Moh. Khusaini ${ }^{2}$ and Atu Bagus Wiguna ${ }^{3}$ \\ ${ }^{1,2,3}$ Faculty of Economics and Business, Brawijaya University, Jalan MT Haryono 165, 65145, Malang, Indonesia
}

\begin{abstract}
Objective - The poverty issue in East Java Province is an interesting research object. This phenomenon has retrieved in every fiscal year, although the intergovernmental transfer funds increase significantly annually. In the decentralization era, a region has been authorized to identify its problem and provide solutions based on their initiatives and preferences. The local government through their budget should focus on their problem solving, i.e. poverty alleviation. Utilizing panel regression, we found that government spending on education and health can reduce poverty rate.

Methodology/Technique - OLS (Ordinary Least Squared) model was utilized to answer the objective of the study, that is, to see how the effect of government spending in various sectors on poverty alleviation.

Findings - Using the panel regression model, this study found that government spending on education has a negative impact on poverty rate in the East Java Province. The impact on this variable appears to be statistically significant.

Novelty - This study showed that central and local government should synchronize their proposed programs, reducing overlapped programs, to pursue a higher efficiency of budget management.
\end{abstract}

Type of Paper: Empirical/Review.

Keywords: Quality Spending, Budget Deficit/Surplus, Poverty Alleviation.

JEL Classification: H72, I31, I32.

\section{Introduction}

There are several debates regarding the effect of government spending on economic performance. Edelberg et al., (1999) highlights this issue and proves that government spending in the US has the potential to raise national output, employment, and non-residential investment, yet other variables such as real wages, residential investment and consumption expenditures fall. Another study presented by Leigh and Neill (2011) argues that government spending, specifically on infrastructure, reduces unemployment in Australia.

Still on the effort to justify the effect of government spending, our paper draws attention to the issue of poverty in Indonesia. East Java as one of the Provincial Levels in Indonesia and has unique characteristics in the poverty alleviation phenomenon. Since the implementation of the Act no 32 of 2004, cnational and local

\footnotetext{
* Paper Info: Revised: September, 2016

Accepted: January, 2017

* Corresponding author:

E-mail: sp83lum@yahoo.com

Affiliation: Faculty of Economics and Business, Brawijaya University, Indonesia
} 
government have been integrating their programs from national to local level. Reference to DJPK data shows that intergovernmental transfer from national to local governments has increased significantly. Moreover, there is a national bureau responsible for poverty alleviation acceleration that has been integrated into the program from national to local levels as well ${ }^{1}$.

However, even at this rate, Statistics Indonesia has published that the poverty rate in East Java has been increasing significantly during the last several years. Another indicator shows that the Poverty Gap Index, is decreasing while the Poverty Severity Index is increasing. This means that while the average consumption of the poor population tends to increase near the poverty line, there is an increase in consumption inequality among the poor.

The idea of fiscal decentralization is a transfer of economic and political power from national to local governments which is implied in intergovernmental transfer. Reference to DJPK data East Java highlights the three highest local revenue sources among the provincial level in Indonesia; the first and second highest local revenue are West Java and Jakarta respectively. Utilizing this fiscal power, however, East Java, based on Minister of Finance law No 37, 2016, has a low fiscal capacity index ${ }^{2}$. At this rate, the fiscal ability of East Java to finance the government program relating to poverty alleviation is still under expectation.

This paper believes the quality of their public spending to be a central issue affecting their fiscal ability. In line with Edelberg et al., (1999) and Leigh and Neill (2011), this study was conducted to find out which expenditure items are considered as the essential spending necessary for economic performance, particularly aimed at reducing poverty rate in East Java.

There are several studies which tend to highlight the importance of quality spending to economic performance. Asghar et al., (2011) and Asghar et al (2012) sought to explore the impact of government spending on economic performance, such as economic growth and poverty in Pakistan. From this research they found that spending on human capital and community service has a positive correlation with economic growth, while spending on education, health and law and order has a negative correlation with the poverty rate. In addition, other sources of spending which were highlighted by the study as sources that did not help to either boost economic growth or reduce poverty, were spending on subsidies, budget deficits and community services.

Other studies of government spending have been conducted previously. Dissou et al., (2016) for example, stated that government spending on education is considered as the engine of growth based on their model. In line with this result, Oluwatobi and Oguninola (2011) found that government spending on human capital and physical capital positively correlated with the level of output in Nigeria. They demonstrated that spending on education has a positive effect on human capital accumulation in the long run and had the potential to increase the national output of a country.

Besides spending on education and human capital, Yu et al., (2011) believes that investment in infrastructure is also an engine of economic development. For this reason, their study sought to explore the reason for a negative trend in spending on infrastructure, specifically in China. The study reveals that government spending on infrastructure has a positive spillover on other regions. To be more specific, if one region increases its spending on infrastructure then another region will reduce their spending on infrastructure, since they believe infrastructure spending in one region will give benefit to the other. Similar findings were presented by Leigh et al., (2011) who observed the impact of spending on infrastructure, specifically spending on roads, on unemployment in Australia.

\footnotetext{
${ }^{1}$ The National Team for The Acceleration of Poverty Reduction (TNP2K).

${ }^{2}$ Fiscal Capacity index is an index published by the Indonesian ministry of finance. It measures the fiscal capacity of a region to solve their economic problem (in this case poverty). If the index is high means that a region have a high fiscal capacity to reduce poverty; if the index is low means that a region have a low fiscal capacity to reduce poverty.
} 
The study found that this type of government spending can reduce local unemployment rates. The explanation is quite similar; that the existence of positive spillover of spending on roads is a key factor in stimulating local employment.

In relation to government health spending, Kruse et al., (2012) has proven that it has strong influence on the poor Indonesian population. From the study, they demonstrated that spending on health lead to the transfer of resources from the richest to the poor. In other words, an increase in spending on health will increase health care utilization to the poorest half of the population.

This study has a contributed to the arrangement of a strategy for encouraging quality spending by the East Java Province in Indonesia, especially in relation to the poverty alleviation phenomenon. At this rate, a previous study has proven that government spending on various sectors has a varied impact on economic performance. Therefore, the local government in East Java needs to consider which spending is the most important because while they have a large fiscal capacity, it is not being used efficiently to reduce poverty.

This paper is organized as follows. The second section will explain the research method and then the empirical research will be discussed. The final section compromises the concluding remarks and policy implications.

\section{Research Method}

The OLS (Ordinary Least Squared) model was utilized to answer the objective of this study, that is to see how the effect of government spending on various sectors affects the ability of governments to reduce poverty. The study is largely developed from the studies of Asghar et al (2011) and Asghar et al (2012) however instead of using a time series analysis, this study employs a panel regression analysis using STATA 13. The model is described as follow:

$$
\operatorname{Pov}_{i t}=\alpha 0+\beta 1 \log (S E d)_{i t}+\beta 2 \log (\text { SHe })_{i t}+\beta 3 \operatorname{Silpa}_{i t}+\beta 4(\operatorname{SInf})_{i t}+\beta 5(\text { SEm })_{i t}+\varepsilon_{i t}
$$

Here, Pov is the poverty rate and is the dependent variable. Several independent variables are used in this study which are: (SEd) as government spending on education in log natural form, (SHe) as govenment spending on health in log natural form, (Silpa) as government budget deficit/surplus, (SInf) as government spending on infrastructure and (SEm) as government spending on employee's salary.

All data in this model is arranged based on city/municipality levels in the East Java Province. The information is collected from DJPK during the period between 2007 and 2014. DJPK (Direktorat Jendral Perimbangan Keuangan) is a unit of the Indonesian Ministry of Finance which focuses on arranging and implementing regulation terms of financial balance between central and local governments. On the other hand, the poverty rate data is collected from Statistics Indonesia.

\section{Result and Discussion}

Using the panel regression model, this study found that government spending on education has a negative impact on poverty rate in the East Java Province (see table 1). The impact of this variable appears to be statistically significant. In other words, a $10 \%$ increase in this type of spending can cause the decrease of the poverty rate in East Java as much as $33 \%$. This means, spending on education is an important variable which needs to be considered when developing strategies to reduce poverty.

On the other side, government spending on health and infrastructure has a positive impact on the poverty rate. In other words, if the government pushes this type of spending, the poverty rate will increase. This is quite ambiguous since previous studies have proved that spending on health and infrastructure is an engine of economic performance and hence could reduce poverty rate. This ambiguity however is not statistically significant.

To make it clear, some independent variables are executed with a one-year lag and the result can be seen on table 2. It shows that spending on health appears as a variable that affects poverty rate negatively. Moreover, 
this effect is found to be statistically significant. If the government raises spending on health by $10 \%$, the poverty rate will decrease as much as $21 \%$. The argument here is that beside the effect itself, the time horizon also needs to be considered to measure the impact of government policy. Therefore, government spending on health in East Java needs at last one year until any reduction in the poverty rate will be seen.

Table 1. The Effect of Government Various Spending on Poverty Rate

\begin{tabular}{|l|l|l|}
\hline & Coefficient & $\mathbf{p}>|\mathbf{t}|$ \\
\hline Spending on Education & -3.340161 & $0.007^{*}$ \\
\hline Spending on Health & 0.0938224 & 0.884 \\
\hline Silpa & -0.1204109 & 0.890 \\
\hline Spending on Infrastructure & 1.749116 & 0.118 \\
\hline Spending on Employee's salary & -3.278379 & 0.412 \\
\hline R squared & 0,7257 & \\
\hline No Obs & 219 & \\
\hline \multicolumn{2}{|l}{ Note: *statistically significant } &
\end{tabular}

After that, whether taking into account the one year lag or not, spending on infrastructure does not show a significant effect on poverty reduction. Several explanations present here. First, infrastructure spending needs a much longer time horizon until it will achieve a significant impact. Second, referring to the Indonesian Ministry of Village development of Disadvantages Area and Transmigration Data, some areas in the East Java Province are categorized as disadvantaged areas in terms of infrastructure, economics, human resources, regional capacity, accessibility and regional characteristics. The point of this argument is the existence of inequality in the development process of the East Java Province which could be a factor affecting the ambiguity in infrastructure spending on poverty reduction.

Table 2. The Effect of Government Various Spending on Poverty Rate (Within one year lag)

\begin{tabular}{|l|l|l|}
\hline & Coefficient & $\mathbf{p}>|\mathbf{t}|$ \\
\hline Spending on Health & -2.198876 & $0.001^{*}$ \\
\hline Spending on Infrastructure & 0.15027 & 0.864 \\
\hline Spending on Employee's salary & -11.12367 & $0.002^{*}$ \\
\hline
\end{tabular}

The silpa variable gives a positive effect on the poverty rate in the East Java Province. Put simply, silpa is a proxy variable used to explain the surplus/deficit of local government budgets. From this point of view, an increasing amount of silpa means that the government budget surplus is increasing and decreasing silpa means that local government budget surplus is decreasing. The finding here is that increasing the amount of silpa will reduce the poverty rate in East Java, however the effect is not significant, implying that this variable does not have a strong correlation with the poverty rate.

The last variable is government spending on employee's salary which appears to be an important variable affecting poverty rate. This variable tends to describe an efficiency of government budget management, where increasing government spending on employee's salary indicates an increasing expense on budget. Therefore, it is expected that the correlation between spending on employee's salary and poverty rate is positive. Surprisingly, within the one-year lag, it is found that a 1 unit increase in government spending on employee's salary will reduce the poverty rate in East Java by $11 \%$.

The argument for this result is that local government has handed over the responsibility of poverty alleviation to national government. Refering to Indonesian Government Regulation No 38 of 2007, local 
government affairs are classified into 26 aspects and not one of them is categorized as poverty alleviation. Furthermore, the existence of TNP2K (The National Team for The Acceleration of Poverty Reduction) as an institution established by the Decree of the President of the Republic of Indonesia Number 15 of 2010, verified that poverty alleviation has become one of the major concerns of the Indonesian national government. Thus, it is believed that the negative trend of the poverty rate in East Java is not directly affected by spending on employee's salary.

\section{Conclusion}

These results shed some light in the literature debate concerning the effect of government spending on economic performance. The finding is similar to that of Edelberg et al., (1999), Asghar et al., (2011) and Asghar et al., (2012) which believe that government spending would encourage economic performance; though this paper gives a broader perspective, having divided the spending into specific sectors and assessing its effect on poverty alleviation. The effect of government spending on education is consistent with Dissou et al (2016) and Oluwatobi and Ogunrinola (2011); that this will unquestionably reduce the poverty rate. The study drawas a similar finding with Kruse et al., (2012) for spending on health, finding that this type of spending has to potential to help those people below the Indonesian poverty line.

However, in contrast with Leigh and Neill (2011) and Yu et al., (2011) our study of government spending on infrastructure did not show the expected impact. Since our model was run over a short term, there were some limitations on the study. Our study of the effect of spending on employee's salary encountered the same problem, which indicates that the impact of budget expenses as well as the budget deficit effect is still questionable.

This paper gives an insight for the relevant policy maker to consider education and health as the most important spending sources for poverty alleviation in the East Java Province. Budget surplus/deficit is believed not to be an as important aspect. Furthermore, unlike the previous study, spending on infrastructure and employee's salary has an ambiguous effect on poverty alleviation.

To pursue high efficiency in budget management, this study suggests that national and local governments should synchronize their proposed programs, such as promoting collaboration between TNP2K and the local government, to reduce the poverty rate in East Java. Following that, areas of overlap need to be reduced such as spending on employee's salary that has increased significantly during the last three fiscal years. In future analysis of the correlation between spending and poverty alleviation or another economic development performance, focus needs to be on incorporating time horizon into the model, thus time series analysis ought to be done.

\section{References}

Asghar, N., Hussain, Z., \& Rehman, H. U. (2012). The Impact of Government Spending on Poverty Reduction: Evidence from Pakistan 1972 to 2008. African Journal of Business Management, 6(3), 845-853

Asghar, N., Azim, P., \& ur Rehman, H. (2011). Impact of Government Spending in Social Sectors on Economic Growth: A Case Study of Pakistan. Journal of Business \& Economics, 3(2), 214-234

Dissou, Y., Didic, S., \& Yakautsava, T. (2016). Government Spending on Education, Human Capital Accumulation, and Growth. Economic Modelling, 58, 9-21.

Edelberg, W., Eichenbaum, M., \& Fisher, J. D. (1999). Understanding the Effects of a Shock to Government Purchases. Review of Economic Dynamics, 2(1), 166-206.

Kruse, I., Pradhan, M., \& Sparrow, R. (2012). Marginal Benefit Incidence of Public Health Spending: Evidence from Indonesian Sub-national Data. Journal of health economics, 31(1), 147-157.

Leigh, A., \& Neill, C. (2011). Can National Infrastructure Spending Reduce Local Unemployment? Evidence from an Australian Roads Program. Economics Letters, 113(2), 150-153.

Oluwatobi, S. O., \& Ogunrinola, I. O. (2011). Government Expenditure on Human Capital Development: Implications for Economic Growth in Nigeria. Journal of Sustainable Development, 4(3), 72. 
Schiller, B. R. (2008). The Economics of Poverty and Discrimination. New Jersey: Pearson Education.

Yu, Y., Zhang, L., Li, F., \& Zheng, X. (2011). On the Determinants of Public Infrastructure Spending in Chinese Cities:

A Spatial Econometric Perspective. The Social Science Journal, 48(3), 458-467. 